\title{
Mapping the Antarctic Polar Front: weekly realizations from 2002 to 2014
}

\author{
Natalie M. Freeman and Nicole S. Lovenduski \\ Department of Atmospheric and Oceanic Sciences and Institute of Arctic and Alpine Research, University of \\ Colorado Boulder, Boulder, CO, USA \\ Correspondence to: Natalie M. Freeman (natalie.freeman@colorado.edu)
}

Received: 23 December 2015 - Published in Earth Syst. Sci. Data Discuss.: 19 January 2016

Revised: 22 April 2016 - Accepted: 26 April 2016 - Published: 12 May 2016

\begin{abstract}
We map the weekly position of the Antarctic Polar Front (PF) in the Southern Ocean over a 12-year period (2002-2014) using satellite sea surface temperature (SST) estimated from cloud-penetrating microwave radiometers. Our study advances previous efforts to map the PF using hydrographic and satellite data and provides a unique realization of the PF at weekly resolution across all longitudes (doi:10.1594/PANGAEA.855640). The mean path of the PF is asymmetric; its latitudinal position spans from 44 to $64^{\circ} \mathrm{S}$ along its circumpolar path. SST at the PF ranges from 0.6 to $6.9^{\circ} \mathrm{C}$, reflecting the large spread in latitudinal position. The average intensity of the front is $1.7^{\circ} \mathrm{C}$ per $100 \mathrm{~km}$, with intensity ranging from 1.4 to $2 .{ }^{\circ} \mathrm{C}$ per $100 \mathrm{~km}$. Front intensity is significantly correlated with the depth of bottom topography, suggesting that the front intensifies over shallow bathymetry. Realizations of the PF are consistent with the corresponding surface expressions of the PF estimated using expendable bathythermograph data in the Drake Passage and Australian and African sectors. The climatological mean position of the PF is similar, though not identical, to previously published estimates. As the PF is a key indicator of physical circulation, surface nutrient concentration, and biogeography in the Southern Ocean, future studies of physical and biogeochemical oceanography in this region will benefit from the provided data set.
\end{abstract}

\section{Introduction}

The large-scale circulation of the Southern Ocean (south of $35^{\circ} \mathrm{S}$ ) is dominated by the strong, eastward flow of the Antarctic Circumpolar Current (ACC), connecting the major ocean basins and allowing for the transport of heat, nutrients, carbon, and other key climate variables globally and to the ocean interior (Rintoul et al., 2001; Sarmiento et al., 2004). The ACC is composed of many deep-reaching hydrographic fronts that divide the Southern Ocean up into physical and biogeochemical zones (see Deacon, 1982; Pollard et al., 2002). The flow of the ACC is concentrated in several jets within which the majority of the circumpolar transport is carried (Rintoul et al., 2001). The terms "front" and "jet" have often been used interchangeably throughout the ACC literature but are distinct features: an ACC front is a water mass boundary that is often associated with an ACC jet, a strong geostrophic current.
While as many as 10 distinct fronts can be realized in the Southern Ocean (Sokolov and Rintoul, 2007), the three majorly recognized ACC fronts are, from north to south, the Subantarctic Front (SAF), Antarctic Polar Front (PF), and southern ACC front (Orsi et al., 1995). At the PF, cold, fresh Antarctic surface waters subduct beneath warmer, saltier subAntarctic waters (Deacon, 1933, 1937). At the surface, the $\mathrm{PF}$ is characterized by strong gradients in temperature, nutrients, and distinct biological communities (Deacon, 1933, 1937; Mackintosh, 1946; Deacon, 1982; Trull et al., 2001). Accurately identifying the location of the PF has been an important and active area of research in recent decades as frontal position has implications for Southern Ocean eddy mean flow, air-sea fluxes, biological productivity, biogeography, and estimates of ACC transport (Hughes and Ash, 2001; Pollard et al., 2002; Sarmiento et al., 2004; Ansorge et al., 2014). 
There are multiple ways to identify the PF using temperature and salinity data collected on hydrographic and bathythermographic sections. A common method uses the $2{ }^{\circ} \mathrm{C}$ isotherm at $\sim 200 \mathrm{~m}$ to mark the subsurface $\mathrm{PF}$, as it is a good approximation of the northern extent of cold, fresh Antarctic Surface Water that generally occupies the upper water column between the PF and the Antarctic continental shelf (Orsi et al., 1995; Belkin and Gordon, 1996). While useful in capturing the vertical structure of the PF on regional scales and over short time periods, in situ data in the Southern Ocean is spatially and temporally sparse, making difficult the study of spatiotemporal variability in the PF.

Satellites have allowed for a large-scale view of the historically under-sampled Southern Ocean. Altimeter images of sea surface height (SSH) reflect features of the upper ocean density field and gradients in SSH have been used to characterize jet intensity and front location (Gille, 1994; Sokolov and Rintoul, 2007; Sallée et al., 2008). Sokolov and Rintoul (2002) demonstrate that regions of strong SSH gradients tend to coincide with particular SSH contours and that the circumpolar path of a particular SSH contour marks the location of an ACC front. However, SSH contouring methods to identify the PF should be approached with caution: Graham et al. (2012) show that an SSH contour is not always associated with an enhanced SSH gradient, challenging the accurate detection of the time-varying front.

Given the signature strong sea surface temperature (SST) gradient at the PF, satellite images of SST can also be used to identify the PF. However, previous PF studies have used infrared retrievals of SST (Legeckis, 1977; Moore et al., 1997, 1999) which are greatly affected by water vapor and clouds, a persistent feature of the Southern Ocean. SST estimates from cloud-penetrating microwave radiometers circumvent the above PF mapping limitations, first demonstrated by Dong et al. (2006b).

Our study learns from and advances previous efforts to map the PF. Herein, we use the continuous, all-weather microwave SST record at $25 \mathrm{~km}$ resolution to estimate the weekly location of the PF from 2002 to 2014. As such, our method avoids water vapor and cloud contamination and provides circumpolar realizations of the $\mathrm{PF}$ at high spatial and temporal resolution. Our realizations of the Polar Front are made publicly available (Sect. 6) so as to benefit studies of Southern Ocean physical and biogeochemical oceanography (e.g., Munro et al., 2015a, b; Freeman and Lovenduski, 2015). In the following sections we detail our PF identification method (Sect. 2), use available expendable bathythermograph (XBT) data to test our method in select sectors of the Southern Ocean (Sect. 3), and discuss the mean path of the PF (Sect. 4). A companion paper investigates spatial and temporal variations in the PF and its linkages with key modes of climate variability (Freeman et al., 2016).

\section{Methods}

\subsection{Sea surface temperature observations}

In this study we utilize daily optimally interpolated microwave SST data, produced by Remote Sensing Systems, on a $25 \mathrm{~km}$ grid; daily SSTs were averaged over 7 days ending on and including the Saturday file date to create a weekly product. This all-weather SST product is derived from in situ estimates and all available microwave SST radiometers operating on a given day between 2 June 2002 and 22 February 2014: the Advanced Microwave Scanning Radiometers (AMSR-E and AMSR-2) and WindSat Polarimetric Radiometer (see Reynolds and Smith, 1994). Data processing involves many quality control measures, including the removal of rain- or sea ice-contaminated SSTs and consideration of diurnal warming and sensor error. It is important to note that there are a few instances in the data record when no radiometer was operational and the SST retrieval from the previous day is used persistently (outages range $\sim 1-7$ days). For further details on data processing and specific dates of SST persistence, the reader is encouraged to visit www.remss.com/measurements/ sea-surface-temperature/oisst-description.

\subsection{Mapping the Polar Front}

We build on the technique first presented by (Moore et al., 1997) of using satellite SST gradient maxima to locate the PF. In general, our PF mapping technique is based on locating the southern bound at which the SST gradient exceeds $1.5^{\circ} \mathrm{C}$ over a $100 \mathrm{~km}$ distance, as in (Dong et al., 2006b). At longitudes where this criterion cannot be satisfied or when large latitudinal distances exist between adjacent longitudes, steps are taken to satisfy spatial and/or thermal continuity, oftentimes as a relaxation of the above limit (see following subsections). Dong et al. (2006b) use $2 \sigma$ and the temporal mean PF to identify such discontinuity. Here, we identify additional physical characteristics of the PF and use this information in a comprehensive mapping scheme. Our methodology does not require knowledge of a temporal mean PF; all information needed to map the PF is found locally. Our mapping scheme yields one continuous, unique $\mathrm{PF}$ realization for a given period of time. In regions where the PF is known to have multiple filaments (Sokolov and Rintoul, 2002), our algorithm typically selects the southernmost.

\subsubsection{PF identification procedure}

South of $40^{\circ} \mathrm{S}$, we compute the absolute SST gradient $\left({ }^{\circ} \mathrm{C} \mathrm{km}^{-1}\right)$ at each grid point,

$|\Delta T|=\sqrt{(\delta T / \delta x)^{2}+(\delta T / \delta y)^{2}}$,

where $\delta T$ is the temperature difference $\left({ }^{\circ} \mathrm{C}\right)$ and $\delta x$ and $\delta y$ are the kilometer distances between any two longitude 
or latitude points, respectively. We do not perform initial, first-guess frontal identification (a) in regions where SST is warmer than $10^{\circ} \mathrm{C}$, as these are waters characteristic of the SAF (Dong et al., 2006b), (b) within small patches of high SST gradients (closed contours less than 3 degrees of latitude and longitude), so as to reduce noise (as in Dong et al., 2006b), and (c) within $1^{\circ}$ of latitude of the Antarctic continent or sea ice, in case of melt-influenced SSTs (Smith and Comiso, 2008).

\subsubsection{Continuity tests}

PF maps are checked for spatial and thermal continuity to determine whether an adjustment in the PF is necessary. Starting at the Greenwich Meridian and moving east, with the general flow of the ACC, we calculate the absolute differences $(d)$ in latitude $\left(1 ;{ }^{\circ}\right.$ latitude), temperature $\left(t ;{ }^{\circ} \mathrm{C}\right)$, and monthly climatological temperature $\left(\mathrm{tc} ;{ }^{\circ} \mathrm{C}\right)$ between the current position and the point to the west $(\leftarrow)$ and east $(\rightarrow)$, twice the standard deviation of these differences (normalized by $N=2), 2 \sigma_{1}\left({ }^{\circ}\right.$ latitude) and $2 \sigma_{t}$ and $2 \sigma_{\mathrm{tc}}\left({ }^{\circ} \mathrm{C}\right)$ respectively, and an additional difference $(\Delta)$ between $2 \sigma$ and $d$ (e.g., $\left.\overleftarrow{\Delta_{1}}=\left|\overleftarrow{d_{1}}-2 \sigma_{1}\right|\right)$. Invoking $t c$ is necessary when injections of polar water from the south or subantarctic water from the north affect frontal identification.

An adjustment in the PF position is required if $2 \sigma_{1}>$ $0.75^{\circ}$ latitude or $\left(2 \sigma_{1} \leq 0.75^{\circ}\right.$ latitude and $\left(\overleftarrow{\Delta_{1}}>0.25^{\circ}\right.$ latitude or $\vec{\Delta}_{1}>0.25^{\circ}$ latitude) ) and any of the following are satisfied:

$$
\begin{cases}2 \sigma_{1}=\overleftarrow{d_{1}} \text { and }\left(\overleftarrow{d_{t}} \geq 2 \sigma_{t} \text { or } \overleftarrow{d_{\mathrm{tc}}} \geq 2 \sigma_{\mathrm{tc}}\right) & \\ \overleftarrow{d_{1}}<2 \sigma_{1}<\overrightarrow{d_{1}}, & \overrightarrow{\Delta_{1}}>1 \\ 2 \sigma_{1}<\overleftarrow{d_{1}} \text { and }\left(2 \sigma_{t}<\overleftarrow{d_{t}} \text { or } 2 \sigma_{\mathrm{tc}}<\overleftarrow{d_{\mathrm{tc}}}\right) & \\ 2 \sigma_{1}<\overleftarrow{d_{1}} \text { and } \overleftarrow{d_{t}}<2 \sigma_{t}<\overrightarrow{d_{t}}, & \overrightarrow{\Delta_{t}}>1\end{cases}
$$

Figure 1 exemplifies spatial and thermal discontinuity according to Eq. (1) and shows the subsequent adjustment made in this particular case (adjustment procedure detailed in Sect. 2.2.3). Here, black plus signs indicate the first-guess PF position (i.e., the southern bound of the 1.5 temperature gradient criterion after removing noise/patches), where the current position being tested for continuity and its immediate neighbors to the west and east are indicated by black open circles. As spatial and thermal continuity is violated in this case (see difference and standard deviation information provided in text boxes), an adjustment in the PF position is made (white plus sign).

\subsubsection{Adjustments}

Following spatial and thermal continuity testing, we identify potential adjustment locations as those that satisfy $\overleftarrow{d_{1}}<2 \sigma_{1}$ and $\overrightarrow{\Delta_{1}}<1$ (see Fig. 1). Here, we locate the southernmost po-

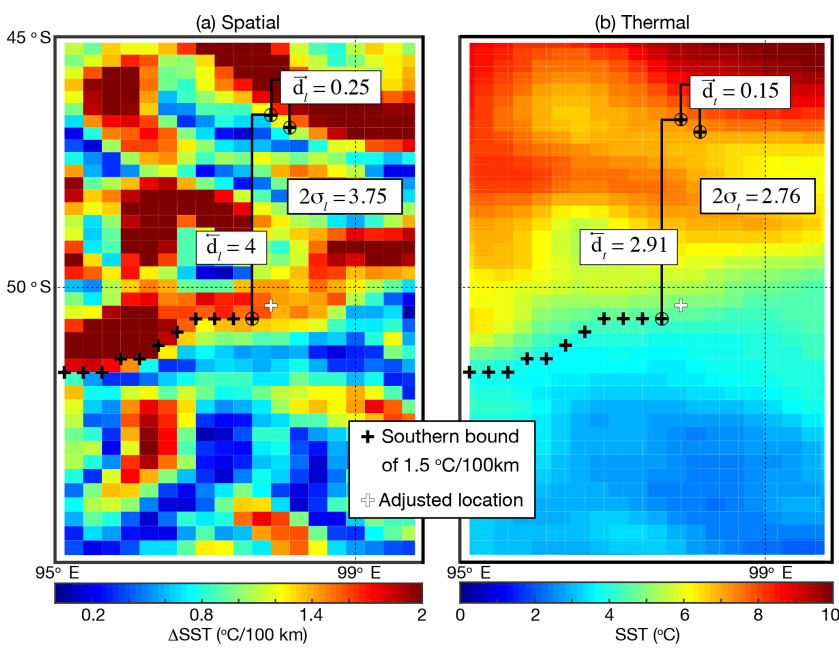

Figure 1. Example of (a) spatial and (b) thermal discontinuity resulting in an adjustment in the PF location according to Eq. (1) as outlined in Sect. 2.2.2. $d_{1}, 2 \sigma_{1}$ in units of ${ }^{\circ}$ latitude and $d_{t}, 2 \sigma_{t}$ in units of ${ }^{\circ} \mathrm{C}$.

sition of the $0.015^{\circ} \mathrm{C} \mathrm{km}^{-1}$ absolute SST gradient. If a gradient of that magnitude is not found, we successively relax the gradient by $0.001{ }^{\circ} \mathrm{C} \mathrm{km}^{-1}$ to a lower limit of $0.011^{\circ} \mathrm{C} \mathrm{km}^{-1}$ in order to find the front. In cases where gradients are relatively weak (i.e., $|\Delta T|<0.011^{\circ} \mathrm{C} \mathrm{km}^{-1}$ ), we use local gradient maxima $\left(>0.008{ }^{\circ} \mathrm{C} \mathrm{km}^{-1}\right)$ to mark the position of the front.

In some cases, spatial or thermal discontinuity is justified. This generally occurs when two filaments are disconnected (Fig. 2a; Sokolov and Rintoul, 2002), or when a branch of the front is predominantly situated north-south (Fig. 2b).

\subsubsection{Post-processing}

In certain sectors of the Southern Ocean, the characteristics of the PF are such that mapping requires executing the above steps in the opposite direction, from east to west, in order to adequately capture the front's curled, folded, or multifilament structure (Sokolov and Rintoul, 2002) or when it merges with or diverges from the SAF to the north (Read and Pollard, 1993; Moore et al., 1997; Cunningham et al., 2003). The following areas of the Southern Ocean are often mapped as outlined in the previous subsections but from east to west: $\sim 20-32^{\circ} \mathrm{E}, \sim 50-62^{\circ} \mathrm{E}$ near Crozet, $\sim 72$ $80^{\circ}$ E near Kerguelen, $\sim 125-150^{\circ} \mathrm{E}$ along the Southeast Indian Ridge, $\sim 170-190^{\circ}$ E in the New Zealand sector, $\sim 200$ $215^{\circ} \mathrm{E}$ along the Pacific-Antarctic Ridge, $\sim 240-300^{\circ} \mathrm{E}$ in the East Pacific, and $\sim 352-360^{\circ} \mathrm{E}$ along the Mid-Atlantic Ridge. 


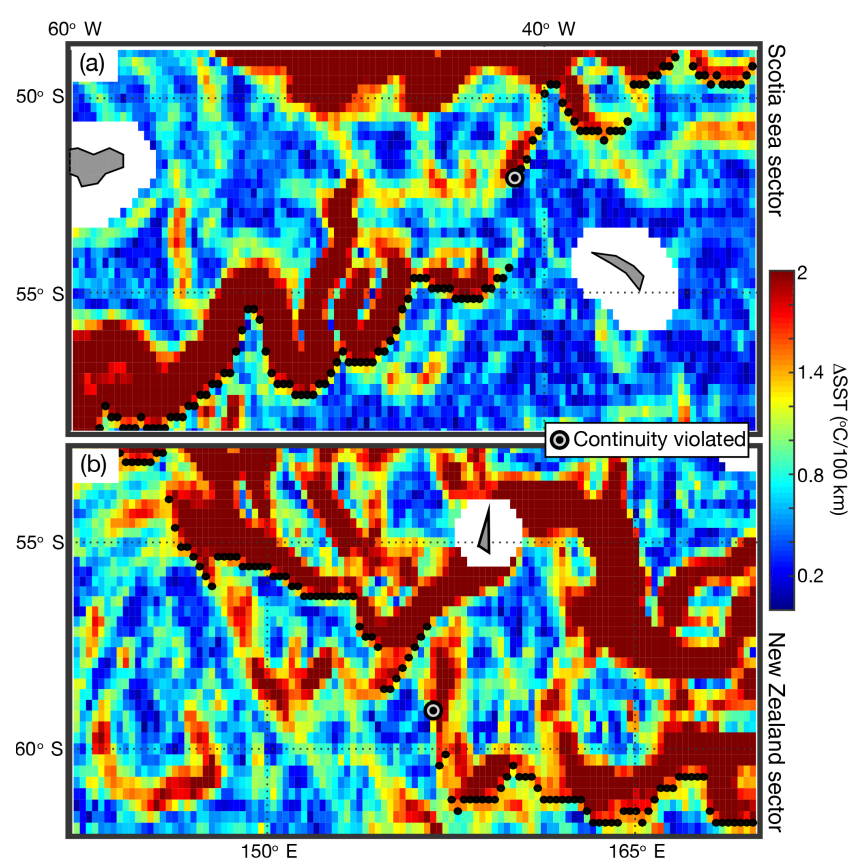

Figure 2. Example cases when spatial and thermal discontinuity is justified: frontal filaments (a) disconnected or (b) situated northsouth.

\section{Validating the PF position}

In order to verify our methods, we compare realizations of PF location to those estimated from high-resolution XBT surface $(<10 \mathrm{~m})$ temperature data. XBT data are available from three Southern Ocean repeat lines: between Hobart, Australia and the Dumont d'Urville Station, Antarctica (line IX28; 64 transects; hereafter referred to as the Australian sector), across Drake Passage (line AX22; 73 transects), and another between Cape Town, South Africa and Sanae IV Station, Antarctica (line AX25; 25 transects; hereafter referred to as the African sector). We note that XBT sampling in the Australian and African sectors is biased to summer and spring seasons, whereas XBT data are collected year-round in the Drake Passage (see Sprintall, 2003).

Along each transect, we interpolate the XBT SSTs to match the satellite grid resolution and compute meridional surface temperature gradients $(\delta T / \delta y)$. We seek to find the in situ PF within 1 standard deviation of the weekly satellite PF location. In the African and Australian sectors, we identify the in situ $\mathrm{PF}$ as the southernmost latitude where $\delta T / \delta y \geq 0.015^{\circ} \mathrm{C} \mathrm{km}^{-1}$. Given the strength of the SST gradient in Drake Passage, we adjust our definition to identify the southernmost latitude of the strongest $\delta T / \delta y$ exceeding $0.015^{\circ} \mathrm{C} \mathrm{km}^{-1}$.

We quantify the error associated with our PF mapping scheme in these three regions by calculating the root mean square error (RMSE), a measure of the average magnitude of the latitudinal differences between the PF inferred from XBT
Table 1. Estimated PF location RMS error (degrees of latitude) and sample size $(n)$, by sector.

\begin{tabular}{lcc}
\hline & RMSE & $n$ \\
\hline Australian sector & 1.1640 & 59 \\
Drake Passage & 0.5373 & 71 \\
African sector & 0.7971 & 24 \\
\hline
\end{tabular}

data $\left(\mathrm{PF}_{\mathrm{X}}\right)$ and that from weekly microwave data $\left(\mathrm{PF}_{\mathrm{M}}\right)$, as

$\mathrm{RMSE}=\sqrt{\frac{\sum_{i=1}^{n}\left(\mathrm{PF}_{\mathrm{X}, i}-\mathrm{PF}_{\mathrm{M}, i}\right)^{2}}{n}}$,

where $n$ corresponds to the number of transects in a given sector. Table 1 lists RMSE and sample size by sector. Transects where a meridional temperature gradient satisfying our $0.015^{\circ} \mathrm{C} \mathrm{km}^{-1}$ criterion could not be identified were excluded from these calculations (eight transects in total).

Differences between in situ and satellite PF locations are likely attributed to one or more of the following: (1) interpolating XBT SSTs on to the satellite grid, (2) differences in the representative temperature measured by the two sources ("bulk" versus "subskin"; see Dong et al., 2006a), (3) errors in the original temperature data (e.g., manufacturer, accuracy, precision, etc.), (4) the regional complexity of the front (i.e., magnitude of mesoscale variability, typical number of branches, etc.), or (5) comparing a daily in situ PF with the corresponding weekly satellite $\mathrm{PF}$.

The PF within the Australian and African sectors (RMSE 1.1640 and $0.7971^{\circ}$ latitude, respectively; $2 \sigma=2.33$ and $2.09^{\circ}$ latitude, respectively), is known for its multi-filament structure (Belkin and Gordon, 1996; Moore et al., 1999; Sokolov and Rintoul, 2002, 2009b), making difficult the comparison between in situ and satellite-based definitions. For example, Fig. 3a shows more than one potential frontal location along a November 2003 transect south of Australia; the in situ PF is identified as the more northerly filament while our weekly PF realization marks the more southerly filament. Figure $3 \mathrm{c}$ shows a summertime African transect where the in situ PF is identified as a more southerly filament and our weekly realization represents the northern, more spatially continuous filament. In Drake Passage (RMSE $0.5373^{\circ}$ latitude; $2 \sigma=1.47^{\circ}$ latitude), the PF is largely constrained by bathymetry (Moore et al., 1997) and characterized by an intense temperature gradient. Figure $3 \mathrm{~b}$ shows a summertime Drake Passage transect where the in situ and satellite PF are identified one grid box apart $\left(0.25^{\circ}\right.$ latitude). Such consistent identifications are reflected in the RMSE here, where on average, our mapping technique will provide PF positions within $\sim 0.5^{\circ}$ latitude of an in situ position in a given week. 

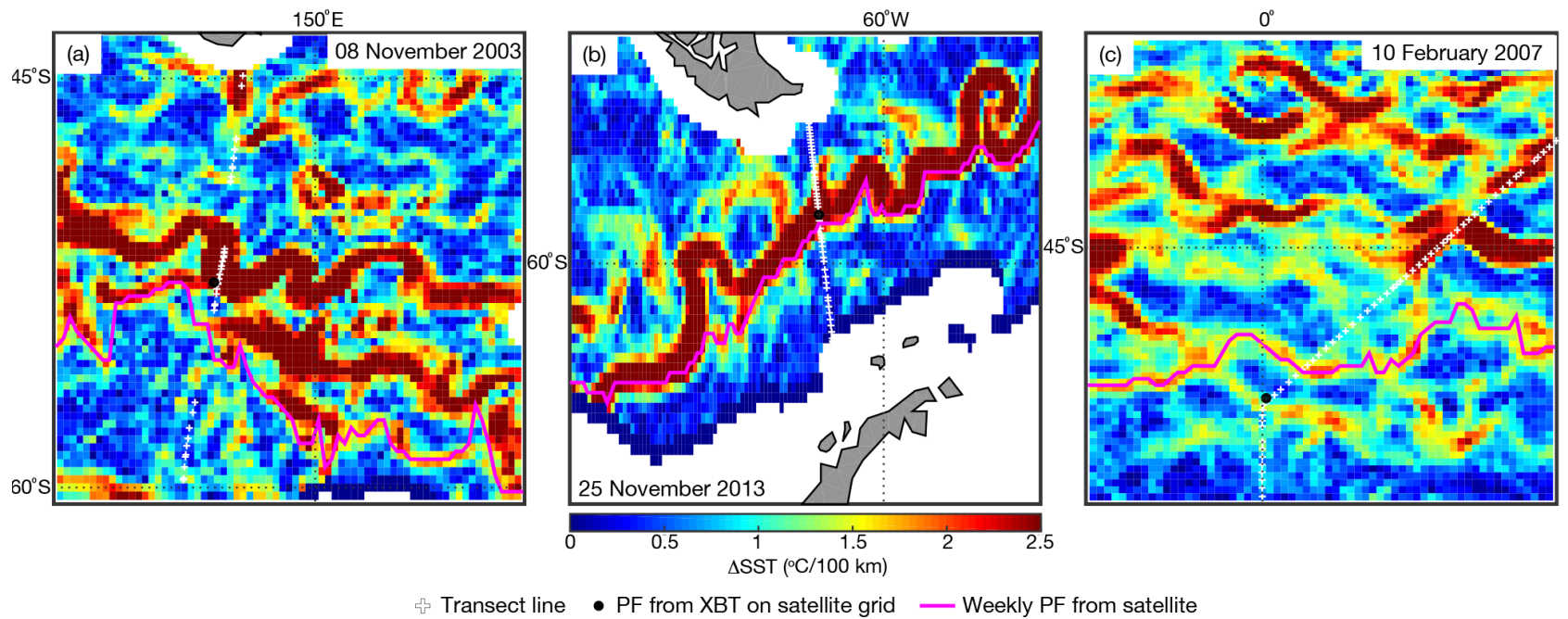

Figure 3. PF location identified from surface XBT data (timestamp indicated) overlain on the corresponding weekly satellite-estimated $\triangle$ SST and PF realization in the (a) Australian, (b) Drake Passage, and (c) African sectors.
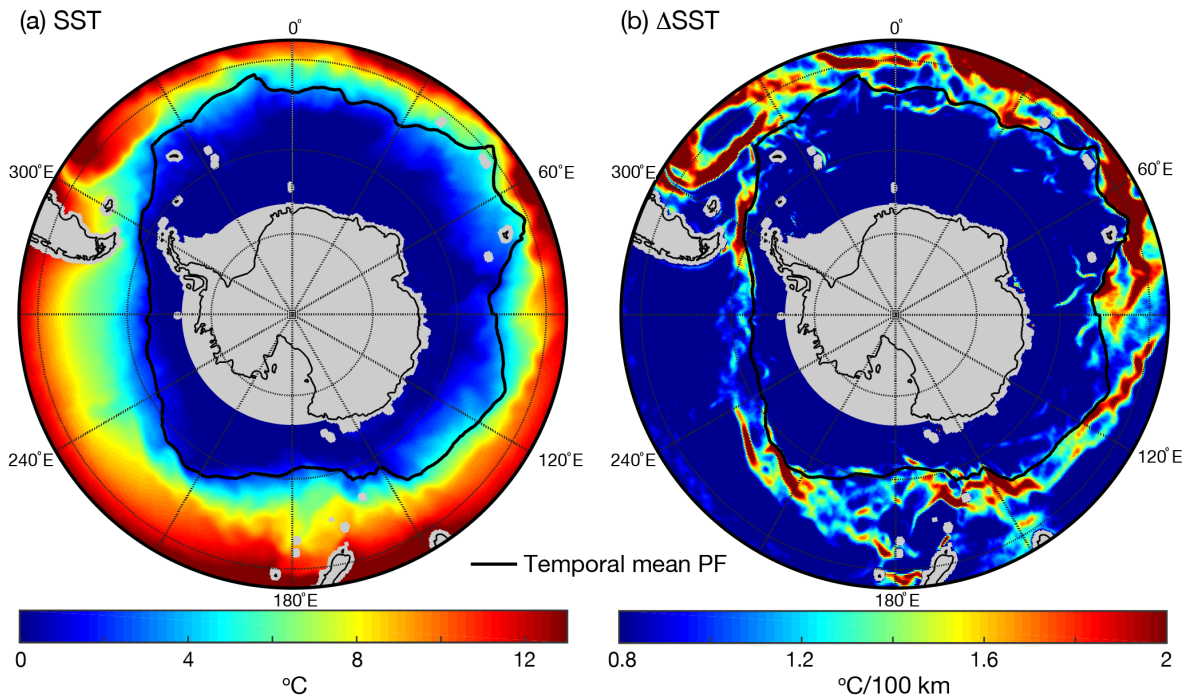

Figure 4. Southern Ocean (a) mean SST and (b) absolute SST gradient with climatological PF overlain (June 2002-February 2014).

\section{Results and discussion}

We investigate the climatological position of the front by averaging weekly realizations over 2002-2014 (Figs. 4, 5). The climatological path of the PF is zonally asymmetric, traversing nearly $20^{\circ}$ of latitude from its northernmost position in the southwest Indian Ocean $\left(43.89^{\circ} \mathrm{S}\right)$ to its southernmost position in the southeast Pacific $\left(64.08^{\circ} \mathrm{S}\right.$; Figs. 4; 5a). It follows that the climatological temperature along the path of the $\mathrm{PF}$ ranges from 0.6 to $6.9^{\circ} \mathrm{C}$ (Figs. 4a; 5b). The climatological intensity of the PF (defined as the absolute SST gradient at the front) averaged over all longitudes is $0.0173^{\circ} \mathrm{C} \mathrm{km}^{-1}$. Climatological intensity ranges from 0.0139 to $0.0225^{\circ} \mathrm{C} \mathrm{km}^{-1}$ (Figs. $4 \mathrm{~b}$; 5c), possibly re- flecting changes in ACC transport along the front (Dong et al., 2006b).

Figure 5 suggests that the mean position, temperature, and intensity of the PF are closely linked to the depth of the underlying topography $(r=0.43, r=0.29$, and $r=0.27$, respectively), in agreement with previous PF studies (Gille, 1994; Moore et al., 1999; Sokolov and Rintoul, 2002; Dong et al., 2006b; Sallée et al., 2008). Indeed, the front tends to be southerly, cold, and weak over the deep ocean, and northerly, warm, and intense over shallow bathymetry. In the southwest Indian sector, the PF is in its northernmost position and characterized by warm SSTs (Figs. 4, 5a, b). Generally, the PF has a more southerly position in the deep, east Pacific sector, characterized by cooler SSTs and relatively weak SST 

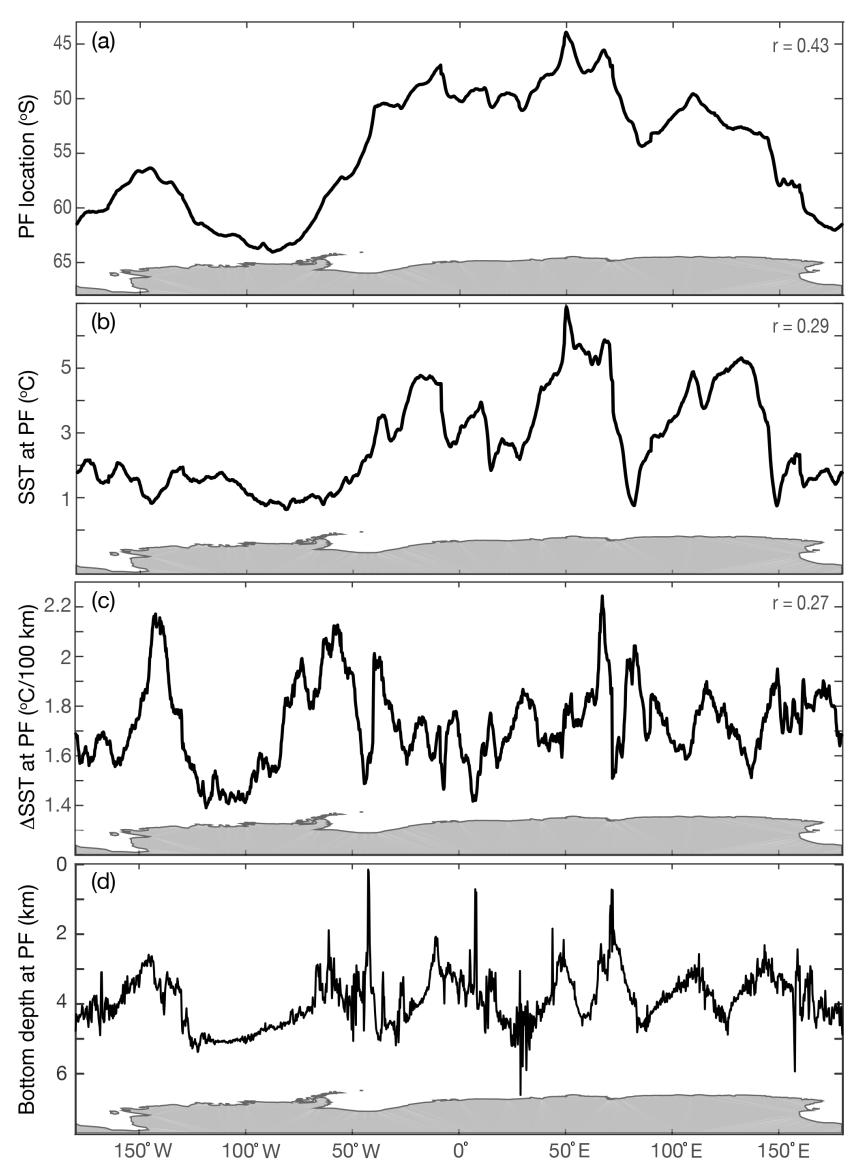

Figure 5. Climatological (a) PF location and (b) SST, (c) absolute SST gradient, and (d) bottom depth at the PF (June 2002February 2014). Statistically significant ( $>95 \%$ ) correlation coefficients with bottom depth are indicated in the top right corner of (a)-(c).

gradients (Fig. 4; Fig. 5; Moore et al., 1999; Dong et al., 2006b). Figure $5 \mathrm{c}$ demonstrates that the PF intensifies at major topographic features, which are associated with strong, large-scale potential vorticity gradients that act to constrain the flow (Gordon et al., 1978; Sallée et al., 2008), including the Kerguelen Plateau $\left(\sim 80^{\circ} \mathrm{E}\right)$, across the Southeast Indian Ridge $\left(\sim 150^{\circ} \mathrm{E}\right)$, Drake Passage $\left(\sim 60^{\circ} \mathrm{W}\right)$, and the PacificAntarctic Ridge $\left(\sim 140^{\circ} \mathrm{W}\right)$.

We compare the climatological position of our PF with that estimated by the studies of Orsi et al. (1995), Belkin and Gordon (1996), Moore et al. (1999), and Dong et al. (2006b) in Fig. 6, where the paths of the front are overlain on a map of bottom topography (Smith and Sandwell, 1994). The topographic influence on the position of the front is apparent: regions of strong topographic steering coincide with regions where all five climatological paths are in good agreement (e.g., along the Southeast Indian and Pacific-Antarctic Ridges in the New Zealand and Ross Sea sectors, through Drake Passage south of the Falkland Islands, and the eastern

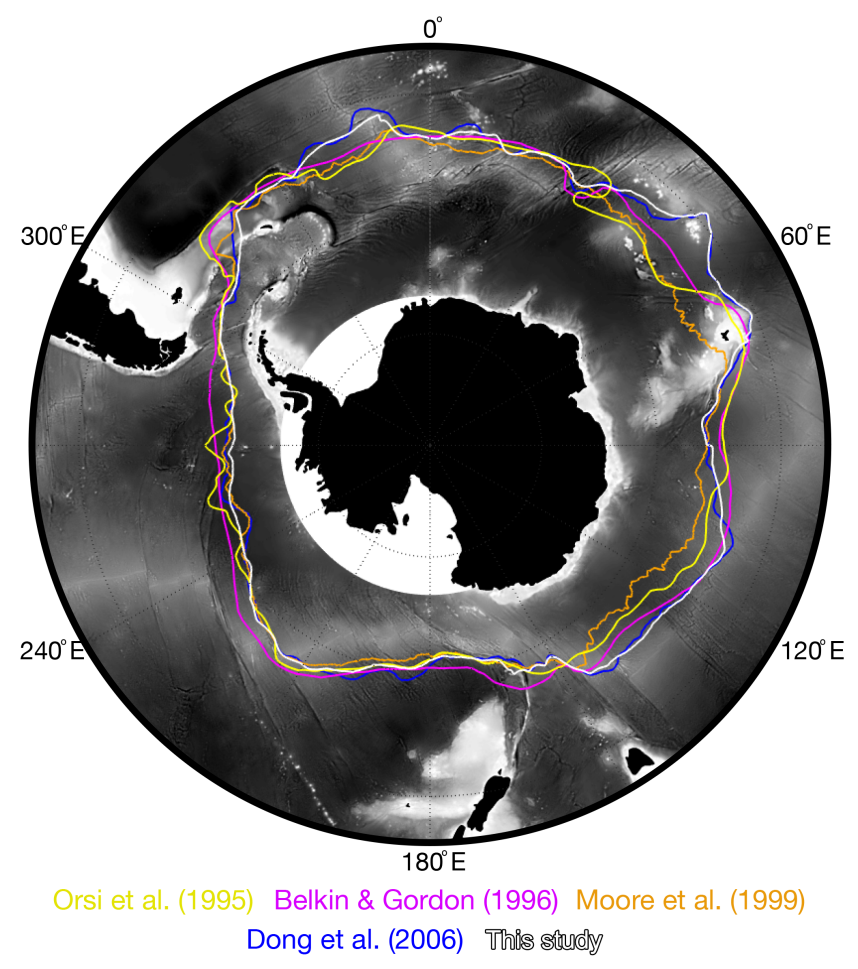

Figure 6. The climatological position of the PF in this and previous studies overlain on bottom topography obtained from the National Geophysical Data Center (www.ngdc.noaa.gov/mgg/dat/ misc/predicted_seafloor_topography/TOPO/), where light (dark) shading indicates shallow (deep) bathymetry.

flank of Kerguelen Plateau) and these paths diverge from one another in deep ocean regions with weak to no topographic steering (e.g., the southeast Indian and Pacific basins).

Given the diversity in the methods and data used to identify the fronts shown in Fig. 6, we do not expect the individual climatological paths to agree everywhere. For example, the Orsi et al. (1995) and Belkin and Gordon (1996) studies use hydrographic data to identify the front's subsurface expression, the northern extent of the $2{ }^{\circ} \mathrm{C}$ isotherm at $\sim 200 \mathrm{~m}$, while Moore et al. (1999) (Dong et al., 2006b) identify the front as an SST gradient using infrared (microwave) satellite retrievals from 1987 to 1993 (2003 to 2005). Our climatological PF diverges most from that of Moore et al. (1999) in areas where persistent cloud cover contaminates the infrared SST retrieval (e.g., $\sim 50-70^{\circ} \mathrm{E}$ and $\sim 110-140^{\circ} \mathrm{E}$ ). Since our study builds on the PF identification method presented in Dong et al. (2006b), it follows that the climatological position of our PF most closely matches that of Dong et al. (2006b).

Our climatological PF merges with the SAF north of the Crozet Archipelago $\left(\sim 50^{\circ} \mathrm{E}\right)$, similar to (Dong et al., 2006b). It passes to the north of the Kerguelen Plateau ( $70^{\circ} \mathrm{E}$ ), as in Orsi et al. (1995), Belkin and Gordon (1996), Dong et al. (2006b), and Sokolov and Rintoul (2009a). South 
of Crozet and Kerguelen, SST gradients are generally too weak to discern frontal filaments.

In the southeast Atlantic sector $\left(330-350^{\circ} \mathrm{E}\right)$, our climatological PF extends further north than previous climatologies. This sector is characterized by many disconnected, smallerscale frontal filaments south of the SAF. The continuity constraint in our method precludes identification of small-scale features as part of the PF, so here the PF follows the strongest and most coherent filament.

\section{Conclusions}

In summary, this study maps the Antarctic Polar Front from 2002 to 2014 at weekly resolution and provides the first temporally varying PF data set derived from SST available to the scientific community. We outline a verified methodology to locate the PF throughout the Southern Ocean using the highresolution, all-weather microwave SST data record. Further, we describe the climatological position, surface temperature, and intensity of the PF and compare our climatological PF to previous studies. As evidence for a variable and changing Southern Ocean grows (Gille, 2002; Böning et al., 2008; Cai et al., 2010; Munro et al., 2015b; Landschützer et al., 2015), determining the response of the PF to such changes is ever more crucial. For an investigation of intra-annual to interannual variability of the PF and associated drivers/mechanisms utilizing this high-resolution PF data set, the interested reader is encouraged to see our companion paper (Freeman et al., 2016).

\section{Data availability}

Weekly PF locations can be found at doi:10.1594/PANGAEA.855640 in netCDF (network Common Data Form) format and viewed as an animation.

Microwave OI SST data are produced by Remote Sensing Systems and sponsored by National Oceanographic Partnership Program (NOPP) and the NASA Earth Science Physical Oceanography Program. Data are available at www.remss. com. Drake Passage and Australian sector XBT data were made available by the Scripps High Resolution XBT program (www.hrx.ucsd.edu). XBT data from the African sector were made freely available by the Atlantic Oceanographic and Meteorological Laboratory and are funded by the NOAA Office of Climate Observations (http://www.aoml.noaa.gov/ phod/hdenxbt/ax_home.php?ax=25). The Orsi et al. (1995) climatological PF position was obtained from the Australian Antarctic Data Center (Orsi and Harris, 2001). Bottom topography data were obtained at www.ngdc.noaa.gov/mgg/ dat/misc/predicted_seafloor_topography/TOPO/ (Smith and Sandwell, 1994).
Acknowledgements. We thank S. Dong for providing her mean PF path. We are grateful for support from NSF (DGE-1144083; OCE-1155240; OCE-1258995) and NOAA (NA12OAR4310058).

Edited by: G. M. R. Manzella

\section{References}

Ansorge, I. J., Jackson, J. M., Reid, K., Durgadoo, J. V., Swart, S., and Eberenz, S.: Evidence of a southward eddy corridor in the south-west Indian ocean, Deep-Sea Res. Pt. II, 119, 69-76, doi:10.1016/j.dsr2.2014.05.012, 2014.

Atlantic Oceanographic and Meteorological Laboratory: High Density XBT Transects AX25, available at: http://www.aoml. noaa.gov/phod/hdenxbt/ax_home.php?ax $=25$, last access: 2 June 2015.

Belkin, I. M. and Gordon, A. L.: Southern Ocean fronts from the Greenwich meridian to Tasmania, J. Geophys. Res., 101, 36753696, 1996.

Böning, C. W., Dispert, A., Visbeck, M., Rintoul, S. R., and Schwarzkopf, F. U.: The response of the Antarctic Circumpolar Current to recent climate change, Nat. Geosci., 1, 864-869, 2008.

Cai, W., Cowan, T., Godfrey, S., and Wijffels, S.: Simulations of Processes Associated with the Fast Warming Rate of the Southern Midlatitude Ocean, J. Climate, 23, 197-206, doi:10.1175/2009JCLI3081.1, 2010.

Cunningham, S. A., Alderson, S. G., and King, B. A.: Transport and variability of the Antarctic Circumpolar Current in Drake Passage, J. Geophys. Res., 108, 8084, doi:10.1029/2001JC00147, 2003.

Deacon, G. E. R.: A general account of the hydrology of the South Atlantic Ocean, Discovery Rep., VII, 177-238, 1933.

Deacon, G. E. R.: The hydrology of the Southern Ocean, Discovery Rep., XV, 1-124, 1937.

Deacon, G. E. R.: Physical and biological zonation in the Southern Ocean, Deep-Sea Res., 29, 1-15, doi:10.1016/01980149(82)90058-9, 1982.

Dong, S., Gille, S. T., Sprintall, J., and Gentemann, C.: Validation of the Advanced Microwave Scanning Radiometer for the Earth Observing System (AMSR-E) sea surface temperature in the Southern Ocean, J. Geophys. Res., 111, C04002, doi:10.1029/2005JC002934, 2006a.

Dong, S., Sprintall, J., and Gille, S. T.: Location of the Antarctic Polar Front from AMSR-E Satellite Sea Surface Temperature Measurements, J. Phys. Oceanogr., 36, 2075-2089, 2006 b.

Freeman, N. M. and Lovenduski, N. S.: Decreased calcification in the Southern Ocean over the satellite record, Geophys. Res. Lett., 42, 1834-1840, doi:10.1002/2014GL062769, 2015.

Freeman, N. M., Lovenduski, N. S., and Gent, P. R.: Temporal variability in the Antarctic Polar Front (2002-2014), J. Geophys. Res.-Oceans, in preparation, 2016.

Gille, S. T.: Mean sea surface height of the Antarctic Circumpolar Current from Geosat data: Method and application, J. Geophys. Res., 99, 255-273, 1994.

Gille, S. T.: Warming of the Southern Ocean since the 1950s, Science, 295, 1275-1277, 2002. 
Gordon, A. L., Molinelli, E., and Baker, T.: Large-Scale Relative Dynamic Topography of the Southern Ocean, J. Geophys. Res., 83(C6), 3023-3032, doi:10.1029/JC083iC06p03023, 1978.

Graham, R. M., de Boer, A. M., Heywood, K. J., Chapman, M. R., and Stevens, D. P.: Southern Ocean fronts: Controlled by wind or topography?, J. Geophys. Res.-Oceans, 117, C08018, doi:10.1029/2012JC007887, 2012.

Hughes, C. W. and Ash, E. R.: Eddy forcing of the mean flow in the Southern Ocean, J. Geophys. Res-Oceans, 106, 2713-2722, doi:10.1029/2000JC900332, 2001.

Landschützer, P., Gruber, N., Haumann, F. A., Rodenbeck, C., Bakker, D. C. E., van Heuven, S., Hoppema, M., Metzl, N., Sweeney, C., Takahashi, T., Tilbrook, B., and Wanninkhof, R.: The reinvigoration of the Southern Ocean carbon sink, Science, 349, 1221-1224, doi:10.1126/science.aab2620, 2015.

Legeckis, R.: Oceanic Polar Front in the Drake Passage - satellite observations during 1976, Deep-Sea Res., 24, 701-704, doi:10.1016/0146-6291(77)90510-0, 1977.

Mackintosh, N. A.: The Antarctic Convergence and the distribution of surface temperatures in Antarctic waters, Discovery Rep., XXIII, 177-212, 1946.

Moore, J. K., Abbott, M. R., and Richman, J. G.: Variability in the location of the Antarctic Polar Front $\left(90^{\circ}-20^{\circ} \mathrm{W}\right)$ from satellite sea surface temperature data, J. Geophys. Res., 102, 2782527833, 1997.

Moore, J. K., Abbott, M. R., and Richman, J. G.: Location and dynamics of the Antarctic Polar Front from satellite sea surface temperature data, J. Geophys. Res.-Oceans, 104, 3059-3073, doi:10.1029/1998JC900032, 1999.

Munro, D. R., Lovenduski, N. S., Stephens, B. B., Newberger, T., Arrigo, K. R., Takahashi, T., Quay, P. D., Sprintall, J., Freeman, N. M., and Sweeney, C.: Estimates of net community production in the Southern Ocean determined from time series observations (2002-2011) of nutrients, dissolved inorganic carbon, and surface ocean $\mathrm{pCO}_{2}$ in Drake Passage, Deep-Sea Res. Pt. II, 114, 49-63, doi:10.1016/j.dsr2.2014.12.014, 2015a.

Munro, D. R., Lovenduski, N. S., Takahashi, T., Stephens, B. B., Newberger, T., and Sweeney, C.: Recent evidence for a strengthening $\mathrm{CO}_{2}$ sink in the Southern Ocean from carbonate system measurements in the Drake Passage (2002-2015), Geophys. Res. Lett., 42, 7623-7630, doi:10.1002/2015GL065194, 2015b.

Orsi, A. H. and Harris, U.: Locations of the various fronts in the Southern Ocean, Australian Antarctic Data Centre - CAASM Metadata, https://data.aad.gov.au/aadc/metadata/metadata redirect.cfm?md=/AMD/AU/southern_ocean_fronts, 2001.

Orsi, A. H., Whitworth III., T. W., and Nowlin Jr., W. D.: On the meridional extent and fronts of the Antarctic Circumpolar Current, Deep-Sea Res. Pt. I, 42, 641-673, doi:10.1016/09670637(95)00021-W, 1995.

Pollard, R. T., Lucas, M. I., and Read, J. F.: Physical controls on biogeochemical zonation in the Southern Ocean, Deep-Sea Res. Pt. II, 49, 3289-3305, 2002.
Read, J. F. and Pollard, R. T.: Structure and Transport of the Antarctic Circumpolar Current and Agulhas Return Current at $40^{\circ} \mathrm{E}, \mathrm{J}$. Geophys. Res.-Oceans, 98, 12281-12295, 1993.

Remote Sensing Systems: Microwave OI SST Product Description, available at: http://www.remss.com/measurements/ sea-surface-temperature/oisst-description, Version 4, last access: 23 April 2015.

Reynolds, R. W. and Smith, T. M.: Improved Global Sea Surface Temperature Analyses Using Optimum Interpolation, J. Climate, 7, 929-948, 1994.

Rintoul, S. R., Hughes, C., and Olbers, D.: The Antarctic Circumpolar Current System, in: Ocean Circulation and Climate, edited by: Siedler, G., Church, J., and Gould, J., 271-302, Academic Press, 2001.

Sallée, J. B., Speer, K., and Morrow, R.: Response of the Antarctic Circumpolar Current to Atmospheric Variability, J. Climate, 21, 3020-3039, 2008.

Sarmiento, J. L., Gruber, N., Brzezinski, M. A., and Dunne, J. P.: High-latitude controls of thermocline nutrients and low latitude biological productivity, Nature, 427, 56-60, 2004.

Scripps Institution of Oceanography (SIO): Drake Passage and Australian sector XBT data, available at: http://www-hrx.ucsd.edu/, last access: 21 April 2015.

Smith, W. O. and Comiso, J. C.: Influence of sea ice on primary production in the Southern Ocean: A satellite perspective, J. Geophys. Res.-Oceans, 113, C05S93, 2008.

Smith, W. H. and Sandwell, D. T.: Bathymetric prediction from dense satellite altimetry, J. Geophys. Res., 99, 21803-21824, 1994.

Sokolov, S. and Rintoul, S. R.: Structure of Southern Ocean fronts at $140^{\circ}$ E, J. Marine Syst., 37, 151-184, 2002.

Sokolov, S. and Rintoul, S. R.: Multiple Jets of the Antarctic Circumpolar Current South of Australia, J. Phys. Oceanogr., 37, 1394-1412, doi:10.1175/JPO3111.1, 2007.

Sokolov, S. and Rintoul, S. R.: Circumpolar structure and distribution of the Antarctic Circumpolar Current fronts: 2. Variability and relationship to sea surface height, J. Geophys. Res., 14, C11019, doi:10.1029/2008JC005248, 2009a.

Sokolov, S. and Rintoul, S. R.: Circumpolar structure and distribution of the Antarctic Circumpolar Current fronts: 1 Mean circumpolar paths, J. Geophys. Res., 114, C11018, doi:10.1029/2008JC005108, 2009b.

Sprintall, J.: Seasonal to interannual upper-ocean variability in the Drake Passage, J. Mar. Res., 61, 27-57, doi:10.1357/002224003321586408, 2003.

Trull, T. W., Rintoul, S. R., Hadfield, M., and Abraham, E. R.: Circulation and seasonal evolution of polar waters south of Australia: implications for iron fertilization of the Southern Ocean., Deep-Sea Res. Pt. II, 48, 2439-2466, 2001. 